Burrow, C.R. 114

Denhardt, D.T. 103

Dragun, D. 185

Fine, L.G. 167

Fogo, A.B. 147

Goligorsky, M.S. 79

Haller, H. 185

Hart, S. 193

Hartner, A. 137

Horton, M.A. 178

Mayadas, T.N. 125
Mundel, P. 160

Norman, J.T. 167

Perantoni, A.O. 80

Pröls, F. 137

Rittling, S.R. 103

Rosenkranz, A.R. 125

Schöcklmann, H.O. 137

Shankland, S.J. 160

Sterzel, R.B. 137

Wilson, P.D. 114

\title{
Subject Index Vol. 7, No. 2, 1999
}

Acute renal failure 185

Adhesion molecules 185

Adhesion receptors 125

Autosomal dominant polycystic kidney disease 114

Basement membrane proteins 80

Cadherins 80

Cell adhesion 137

- proliferation 160

Cytoskeleton 160

Delayed graft function 185

Endothelium 185

Extracellular matrix 137, 167

Fibrosis 167

Focal adhesion 114

Gene therapy 193

- targeting 80

Glomerulosclerosis 147

Glomerulonephritis 125

Inflammation 125

Injury 103

Integrin(s) 80, 114, 137, 167, 178, 193

Interstitial fibroblasts 167

Knockout mice 103,125
Liposomes 193

Macrophages 103

Matrix 114

- receptor 114

Mesangial cells 137

- matrix 147

Nephrotic syndrome 160

Non-viral 193

Osteopontin 103

Peptides 193

Peptidomimetics 178

Plasminogen activator inhibitor 1147

Platelet gpIIbIIIa 178

Podocyte foot process fusion 160

Renal development 114

- diseases 178

Renin-angiotensin system 147

Reversal, sclerosis 147

RGD peptides 178

Selectins 80

Targeting 193

Vitronectin receptor $\alpha_{v} \beta_{3} 178$ 